\title{
Private Equity in the UK: Job Regulation and Trade Unions
}

\author{
lan Clark \\ University of Birmingham, UK
}

\begin{abstract}
Private equity represents a 'new actor' in the British business system with the capacity to have a significant impact on industrial relations. However, while private equity and its associated business model appear as significant factors in corporate governance and industrial relations, neither the sector nor the business model has been evaluated theoretically or empirically. Indeed, for the UK at firm level the ways in which business strategy and job regulation are shaped by private equity are unclear other than by references made to institutional configuration in the business system - short-termism. This article outlines what private equity is, details its associated business model, describes how the sector affects workers and summarizes how trade unions have responded to the private equity business model.
\end{abstract}

Keywords: collective bargaining; private equity business model; 'take private'; trade unions; transfer of undertakings

Contact address: Ian Clark, International Management and Organization Research Group, Birmingham Business School, The University of Birmingham, University House, Edgbaston, Birmingham B 5 2TT, UK. [email: i.a.clark@bham.ac.uk] 


\section{Introduction}

The term 'private equity' refers broadly to any type of equity investment in an asset that is not freely tradable on a public stock market. These types of investment range from start-up and 'seed' capital supplied to entrepreneurs by venture capitalist investors to larger passive investors who put money into private equity funds that are in turn used by private equity fund partnerships to buy and 'take private' large mature businesses. Today, the majority of private equity investment falls into the 'take private' category. Currently io percent of the UK workforce is employed in private equity owned businesses and I9 percent of the workforce is employed in firms that have at some stage been in private equity ownership (House of Commons Treasury Committee [HCTC], 2007: 7). Outside the USA, the UK is the most developed market for private equity, accounting for 50 percent of all private equity investment in Europe in 2005 (British Venture Capital Association [BVCA], 2006: 5). In 2006, UKbased fund managers raised $£_{34} \mathrm{bn}$ and in the same year there were 304 deals based on the private equity business model (PEBM), Ioo of which were valued at less than $£_{5} \mathrm{~m}$ and 25 of which were valued at over $£_{25} \mathrm{Om}$. In 2007 , the Alliance Boots deal brokered by Kohlberg, Kravis and Roberts (KKR) was costed at $£_{\mathrm{I}} \mathrm{bn}$, and was the UK's largest ever deal. It was also the first PEBM buy-in to a FTSE Ioo company (HCTC, 2007: 5).

The significance of private equity and the PEBM, particularly its 'take private' variant, is that the institution and the model each have the potential to shape employer behaviour towards job regulation, both directly and indirectly. Accordingly this article addresses three questions. First, what are the implications of private equity and the PEBM for collective bargaining and trade unions in the British business system? Second, what are the direct firm level pressures on management and workers that flow from the diffusion of the PEBM. For example, a firm acquired by a private equity investor may be subject to significant financial, commercial and organizational restructuring, each of which is likely to have an impact on industrial relations. The third question is what are the more indirect consequences of the PEBM on business more generally? The acquisition by private equity may have a significant direct effect on industrial relations at firm level, but this may not always be the case. However, over time more widely across the British business system the indirect effects of the PEBM and associated strategies, such as hostility to 'inherited' collective bargaining and 'union busting', may appear as best practice innovations beyond private equity backed firms.

The remainder of the article divides into four sections; Section 2 outlines the nature of private equity, and provides a detailed evaluation of the PEBM. Section 3 summarizes the research methods and sources that were drawn on to develop the argument in the article. Section 4 describes how the PEBM affects employees, while Section 5 summarizes how trade unions have responded to private equity and the PEBM. 


\section{Private Equity and the Private Equity Business Model}

\section{Defining Private Equity}

In the main institutional investors in Britain invest in publicly-quoted firms on London's stock exchange in two ways: one via equity markets, and two via investment in debt-based funds in the form of debentures. The latter give debt holders creditor status over company assets in the event of default or bankruptcy. Recently there has been significant growth in capital flowing into private equity funds. This growth has been so extensive that the private equity sector within Britain's capital market now provides a specific business model designed to support start-up and established businesses. It involves innovative commercial and operational strategies centred on sophisticated financial management and debt leverage that aim to enhance company efficiency. The rationale for the model is firmly located in agency approaches to the theory of the firm and corporate governance, and hence gives priority to shareholder rather than stakeholder interests in governance.

Private equity fund management partnerships are one part of a highly stratified fund management and venture capital sector that comprises three components. First, there is a large group of small entrepreneurial firms that focus on smaller domestic transactions. These providers are often termed venture capitalists and look to support promising business ventures in search of start-up and 'roll-out' capital. A second group of larger firms tends to focus on domestic transactions in the form of management buy-outs of, or in some cases management buy-ins to, established but predominantly mid-market Britishbased businesses. A third group comprises fewer but much larger multinational funds that undertake very large domestic and international transactions on the private equity business model. The contemporary activity of firms and their fund managers in the second and third segment of the sector extends beyond private firms, with many firms becoming renowned for 'take private' deals of publicly-listed companies or parts of them. In these deals, private equity firms (using a combination of equity and debt) may act by themselves or, in a consortium of banks, individuals or sovereign wealth funds, buy-out all the publicly quoted shares in a company thereby taking the company private. Operationally, private equity firms establish and operate collective investment schemes and advise on, assess and manage investment deals for clients (Financial Services Authority [FSA], 2006: 79). These groups are predominantly funded by institutional investors such as pension funds, commercial and retail banks, insurance companies, government agencies and local authorities (see Clark, 2007).

To summarize, many private equity firms are unlisted limited partnerships made up of general partners (the fund managers) and limited partners (the investors) who provide the bulk of the investment capital for the fund. The PEBM rests on the sophisticated use of financial engineering to transform 'cheap' or 'under-performing' businesses. Hitherto public companies owned by private equity partnerships are freed from the burden of quarterly reports and associated transparency. As a result private equity firms can manage businesses run 
on the PEBM to emphasize governance principles based on direct ownership and agency rather than on a separation of ownership and control.

\section{Agency and the PEBM}

Advocates of the PEBM reject the utility of managerial theories of the firm that emphasize managerial discretion and shareholder deference to professional salaried managers (Berle and Means, I932; Chandler, I977; Marris, I964; Means, I930; Williamson, 1964, I967). Instead the model draws on agency theory (Jensen and Meckling, I976) and focuses not on institutionally-embedded patterns of efficiency and organizational capability in national variants of managerial capitalism (America and the UK in particular) but on the waste and inefficiency of managerial discretion for shareholders. Thus, within the PEBM there is a contractual approach to management and investment returns that in effect takes the form of a partnership agreement between fund managers and professional institutional investors.

Agency relationships exist when one or more persons - the principals-engage other individuals - the agents - to perform a service on their behalf. This will necessarily involve some delegation of decision-making authority to the agent. In managerial theories of the firm this is referred to as managerial discretion. Theoretically, the cost of managerial discretion to the owners of a business and/or the investors in a business is a residual loss. Historically, residual losses arising from managerial discretion were acceptable during the post-war economic boom as industrial concentration in the American and British business system facilitated technical innovation that, in turn, secured reduced unit costs and sustained profit levels (see O'Sullivan, 2000: I05-46). However, this can only be regarded as successful because the discretionary base of management provided them with countervailing power relative to trade unions, consumer organizations and government regulation (Galbraith, 1952, 1967). In the contemporary period, the PEBM is specifically geared towards minimizing residual losses in an altogether different way to the manner suggested by those managerial theories which accept the losses associated with the separation of ownership and control. Thus, the key difference between national variants of managerial capitalism and the PEBM is a distributional one and in the legitimacy accorded to countervailing interests. To a degree, post-war managerial capitalism was inclusive of these countervailing power interests whereas in the contemporary period deregulation has created an environment where social exclusion of consumer and worker interests is acceptable and encouraged.

Agency theory predicts that owners and investors such as private equity fund managers can limit both managerial opportunism and the countervailing interests of non-shareholder stakeholders through a combination of incentives and monitoring mechanisms. Research has found that it is often the case that private equity fund managers incentivize managers to perform like owners by linking remuneration to firm performance. Senior management can be incentivized to do so by equity options linked to future performance and direct share 
ownership, sometimes gifted to them in the form of 'sweet equity'. Evidence gathered on private equity engagement with acquisitions in the UK suggests that performance management is a private equity investor concern in 79 percent of cases, with executive stock options and incentives utilized in 32 percent of cases to incentivize management to deliver on contractual conditions (Martin et al., 2007: 84-8). In addition to this, agency approaches to management are evident in performance monitoring imposed on middle management and worker teams. In the majority of case studies of private equity buyout companies, shorter-term performance metrics and performance targets were introduced as a direct result of private equity ownership and control. This is reminiscent of Alchian and Demsetz's (1972) description of the managerial problem of 'shirking' in team production and Edwards' (1979) description of technical and bureaucratic control over management and workers. So, in theory, private equity is an agency model that minimizes the disjunction between investors and owners and employees, whether senior management or workers, by a combination of incentives and self-imposed monitoring that reduce the residual losses incurred by management discretion, which are seen as acceptable within alternative managerial approaches to the firm.

\section{Private Equity Fund Managers are Not Magicians but They Very Nearly Are}

The PEBM operates in a highly leveraged manner. The debt component as a percentage of an acquisition is often very high - up to 70 percent in many cases and much higher in some others. For example, KKR invested less than £ı $\mathrm{rbn}$ of its own money in the £ I I bn acquisition of Alliance Boots. The effects of high leverage are evident in two ways. The first is related to exit. Fund managers aim to sell-on acquisitions within a five year time frame often via a new public offering of shares, thereby returning a business to the listed market. This enables private equity partners to repay their debt to investors, secure their tax breaks, and pass on the firm's debt. For example, debts that result from sale and leaseback of property portfolios or an underfunded pension scheme remain on the balance sheet of the acquired firm (not the private equity investor) and are therefore easily passed to a new firm. Second, the effects of high leverage are observed in cost reductions and divestments or out-sourcing to reduce debt. For example, HR might be outsourced on a shared business model. In terms of employment relations, extra value may be extracted by 'harder' HRM and adoption of 'low road' strategies for workplace agreements on substantive and procedural terms and conditions of employment (HCTC, 2007: I I-I 7, $30-6)$.

\section{Methods and Sources}

The researcher initially came across the term 'private equity' in fieldwork examining HRM in US multinationals (Clark and Almond, 2004). ${ }^{1}$ These references were subsequently followed up and further developed in work commissioned by the Financial Services Authority and the Treasury Select Committee for its 
examination of private equity (Clark, 2007; FSA, 2006; HCTC, 2007). The commissioned work examined the extent to which acquisition, ownership or control by private equity results in patterns of management and job regulation, which are characteristic of the private equity stereotype, particularly its 'take private' variant. The findings presented in Section 4 draw on qualitative semistructured case study interviews with interview respondents from the BVCA, the FSA, two of the largest private equity funds based in the UK specializing in 'take private' deals, legal officers, regional convenors and general secretaries of the GMB and UNITE trade unions, lay trade union representatives and workers, and customers of firms that are owned or controlled by private equity. Twenty formal face-to-face interviews were conducted. Apart from the customer interviewees, each of the respondents had extensive involvement and experience in several high profile cases of private equity-backed buy-outs and subsequent employment relations restructuring. In addition to this primary material, secondary source material is drawn from sources as diverse as the BVCA, the International Trade Union Confederation, regulatory authorities such the FSA, government departments, and private equity partnerships themselves.

\section{What Does Private Equity Do to Workers?}

Although first developed in the American business system in the early I980s the PEBM is a 'stateless development'. Firms subject to the model are subordinated to the competitive logic of global capital markets rather than the real economy for goods and services in the national business systems in which they are located. At firm level the direct effects of the PEBM on workers can be immediate: a GMB union campaign argues that in firms acquired by private equity, employees are likely to experience job cuts, work intensification and, in some cases, a regime of workplace 'bullying' in order to accommodate and accept the management of change (see http://www.GMB.org.uk).

\section{Change Management, Asset Stripping and Liability Dumping}

At the Bird's Eye Hull plant private equity owners closed the plant after five months of operation without any notice and transferred 600 jobs to Germany. At the Automobile Association (AA), private equity owners de-recognized the trade union, ended check-off arrangements, and offered to pay staff subscriptions to a new 'scab' 'staff association' led by a former GMB official. They subsequently offered redundant staff an $£$ I 8 , ooo 'take it or leave it' offer that was reduced to $£_{2} 2,000$ in the second round of redundancies. Under the terms of the de-recognized collective bargaining agreement, longer serving employees could have received redundancy payments of up to $5_{5}$,, 000 . In total the AA made over 3500 workers redundant ( 35 percent of the workforce) resulting in fewer patrol staff, a less comprehensive out-of-hours service and reduced cycle times for patrol staff to diagnose breakdowns. In effect, the latter has resulted 
in many AA members experiencing a 'tow not fix' service as patrol staff have only I 5 minutes per breakdown (if patrol staff think a repair or re-start will take more than 15 minutes the vehicle will be towed to a garage) (interview notes and TSC/GMB, 2007). ${ }^{2}$ NCP car parking has passed through the hands of three private equity owners in under two years with successive sales extracting over $£ 8$ oom in profits for the funds. The current owners of NCP car parking have sought to de-recognize the trade union and remove annual staff bonuses.

Not all of the respondents reported 'lower road' restructuring. The material collected shows a range of management approaches in firms controlled by private equity, not just the more familiar negative ownership cases often referred to in the media. While the evidence cited by the GMB in respect of the AA, Bird's Eye and NCP is a matter of public record, the private equity sector consistently refuses to respond in public. Requests for access to portfolio companies or private equity funds are consistently declined. Hence while unions are right to campaign against private equity and the PEBM, the typicality of cases such as the AA, Bird's Eye, NCP car parks and several others cannot be objectively evaluated. There is some academic evidence that reports a positive effect of private equity and venture capital ownership on employment levels (see Bacon et al., 2004; Wright et al., this issue).

Significantly but less well publicized, workers in private equity-owned firms have seen their pension schemes wound up because there are insufficient funds to meet liabilities. In addition, in some cases the sponsoring employer or its subsidiary has been declared insolvent. Of course, wind-up and insolvency is not restricted to businesses owned by private equity. However, union critics of private equity acquisition argue that pension scheme funds are either used to help collateralize an acquisition or existing deficits are deepened as private equity owners take pension holidays and fund deficits with loans. Currently there are 59 PEBM backed schemes in the Financial Assistance Scheme (which is funded and underwritten by the taxpayer) (GMB Union, 2007: IO).

If there is some debate in respect of the effects of private equity ownership on workers, other less direct effects associated with the PEBM are undeniable. Workers lose out indirectly as taxpayers; for instance it is the latter who fund the financial assistance scheme. The Exchequer loses out due to the tax breaks afforded to the PEBM that allow for the interest on the debt incurred to acquire a firm to be partly written off against tax. For example, KKR's acquisition of Alliance Boots will cost the Exchequer around $£_{\mathrm{I}} 5 \mathrm{Om}$ in lost corporation tax. An associated danger here is that the PEBM could become a 'best practice' template for more responsible non-private equity firms who see themselves at a competitive disadvantage in terms of tax payments and hence revenues available to satisfy shareholder value. Early non-private equity adopters of the PEBM include British Airways (BA), which is part of a private equity consortium aiming to acquire Iberia (the Spanish national airline), and Tata, the Indian conglomerate which financed its acquisition of Corus using the PEBM, a practice it then repeated in the acquisition of Jaguar and Land Rover. 


\section{How Have Trade Unions Responded to the PEBM in the UK?}

Despite the significant presence of the PEBM in the British business system and growing media and regulatory concern, academic attention is less extensive in the industrial relations literature than in the financial economics and political economy literatures. This is the case despite considerable trade union comment and concern about the effects of the PEBM on industrial relations and human resource management at firm level post-buy-out. Indeed such is the momentum of the GMB trade union campaign to defend collective bargaining, that it is credited in political circles with embarrassing the Treasury into establishing a Select Committee on private equity.

The GMB and UNITE union each campaigned to publicize the effects to members of private equity acquisition of companies. The GMB campaign in particular was more sophisticated than just calls for industrial action. It involved numerous publicity stunts designed to raise media and political attention. Some of the stunts targeted well-known but publicity shy private equity fund managers who had refused to have anything to do with unions, arguing that the businesses they controlled had made voluntary and lawful decisions to de-recognize collective bargaining agreements. As these stunts gave way to well-organized newsprint, radio and TV campaigns, unions began to focus on the transparency and taxation implications of the PEBM in order to attack the distributional consequences of the model. In early 2007, parts of the financial press, the Financial Times in particular, and some members of the private equity sector, such as Jon Moulton of Alchemy partners and Labour supporter Ronald Cohen of Apex partners, suggested that regulation of the sector was inevitable. This culminated in the Treasury Select Committee examination of the private equity sector and an attempt at self-regulation in the form of a code of conduct for the sector (Walker Report, 2007). Following on from initial publicity campaigns, union responses to the FSA, the Treasury select committee, and the Walker review code of conduct became more sophisticated and well organized. These union responses emphasized four substantive industrial relations issues.

\section{Taxation}

Unions have argued that a clear distinction between taxation of companies and taxation of individuals and their personal income is necessary. For example, private equity fund managers, managers in acquired firms, and employees with share options are all currently able to declare their profits on share ownership and share options as a capital gain not earned income. The tax breaks were not designed to help huge private equity 'take private' deals such as those associated with Alliance Boots or EMI, but were aimed at supporting small venture capital firms in entrepreneurial developments in need of seed corn and start-up cum roll-out funding. The union objection, and that of the Treasury Select 
Committee, is both distributional and equity-based. Fund managers and operational managers in acquired firms currently pay less taxation on their profits from share income than do workers in PAYE contributions. The situation has become less fair since April 2008 as the ro percent band of taxation for lower paid workers was abolished at that time. So even if profit on share income is taxed at 18 percent this is still less than the base rate for income tax levied on the low paid.

\section{Collective Bargaining Agreements and Transfer of Undertakings}

The Transfer of Undertakings Protection of Employment (TUPE) regulations as they currently stand do not cover transfer of business ownership through majority share sales, that is, where the firm remains intact but its controlling owner changes. A change of this type is not treated as a change of ownership affecting industrial relations as far as the law is concerned. In effect this allows a new owner to de-recognize a trade union, disregard any collective bargaining agreement and restructure the firm and its pattern of job regulation in a manner that is not possible in more traditional merger and acquisitions. Unions have called for the TUPE 2006 regulations to be extended to cover acquisitions through majority share sales and have further called for European Union (EU)-wide consideration of the impact of the PEBM on: TUPE, the Acquired Rights Directive, the Information and Consultation Directive, and the Takeover Panel Secrecy Code. The latter issue is important because discussion of a potential PEBM acquisition with a recognized trade union and/ or disclosure of a business plan for such an acquisition would breach stock exchange rules and the takeover panel secrecy code. This point is used by some, the BVCA for example, to argue that TUPE can never be applicable in cases of acquisition by change of majority shareholder. The contrary view is that these difficulties demonstrate the need for the extension of TUPE provisions to all types of acquisition, including those of public sector workers transferred to the private sector through share acquisition. However, while this extension is easy to argue, it will be much more difficult to achieve in practice and this is a major challenge for the union movement and its academic and political supporters.

\section{Disclosure and Transparency}

Currently private equity firms do not have to disclose who their investors are, where they are domiciled, how they are paying for their stake in a fund, or how much they pay themselves, the management-turn-around teams, and consultants they parachute into acquired firms. The GMB and the UNITE union have each campaigned for clearer disclosure rules on the payment of fees and charges levied by private equity owners. The lack of disclosure and transparency is even more pronounced in respect of share buy backs and re-capitalizations. An acquired firm will fund a buy-back or a re-capitalization of its overall financial structure by taking on more debt; buy backs and re-capitalizations are usually 
used to fund special dividend payments to equity owners, that is, fund managers and other investors. What is peculiar to the PEBM is that this type of dividend payment comes from debt not profit, with the debt remaining on the balance sheet of the acquired firm. This practice is entirely lawful in the UK.

\section{Pension Funds and Property Portfolios as Collateral}

A unique feature of the PEBM is the use of assets in an acquired firm as collateral for the purchase of the firm. A common feature of the PEBM is sale and leaseback of company assets. While the sale of assets yields significant cash flow, leased-back rents become an additional leakage from profits. Depending on the length of the lease they could become more burdensome in the future or lead to the loss of outlets as landlords dispose of leases in more attractive ways. Pension funds can be used in this way as collateral and, post acquisition, a pension fund can be transferred to a less solvent subsidiary. Both practices are lawful in the UK, as is the separation of pension schemes from sponsoring firms through the sale of schemes in the secondary private equity market. In effect, for a fee, providers manage pension schemes on a shared business model and make their margin out of securing economies of scope by administering several schemes. Thereafter, schemes may become frozen or insolvent if new owners take payment holidays to boost cash flow and profitability or if the original sponsoring business goes into liquidation. Although each of these practices is subject to the provisions of the Pensions Act 2004 they are all more or less unregulated, as all the regulator is required to judge in these cases (guided by pension scheme trustees) is whether on balance the company has deliberately dumped the scheme or whether they have undertaken a risky restructuring. Unions have called for each of these areas to be better regulated. For example, the GMB and UNITE argue that the pensions regulator should be required to consult with recognized unions as well as pension trustees. More significantly, unions have called for PEBM business plans to rank pension scheme obligations ahead of investor interests in the event of any insolvency. Currently this is not the case and if a pension scheme ends up in the financial assistance scheme or the pension protection plan, taxpayers, workers, and employers with properly-ordered schemes foot the bill.

\section{Summary and Conclusions}

The significance of the PEBM in the British business system is threefold. One, it represents a new organizational form and associated business model that can be conceptualized in terms of a strong agency approach to corporate governance. At a system level its competitive logic threatens to challenge established institutional interests that extend beyond those of investors and shareholders. Below this, at firm level, the results of this logic become evident in strategic choices to de-recognize collective bargaining arrangements in the interests of shareholder value and improved cash flow. Two, the high returns achieved by 
private equity investments in the UK over the recent past threaten to establish 'lower road' compliance approaches to industrial relations that are sometimes associated with the PEBM as a model for lawful contractual agreements. Third, less immediately direct but potentially of long lasting significance, the PEBM and its associated business and industrial relations strategies may become a new 'best practice' template for non-private equity firms in a quest for sustained competitive performance (possibly to deter predatory acquisition by private equity).

Is private equity a significant actor or an over-hyped hot topic for academic research in industrial relations? It is the case that only one of the FTSE top roo firms is controlled by private equity. It is also the case, however, that at least Io percent of private sector employment is controlled by private equity. Even so, the vast majority of employment is beyond the control of private equity. However, this may well change. It is worth remembering that just io years ago private equity ownership was in large measure confined to venture capitalists and hedge fund investors. As trade union campaigns have made clear, the impact of private equity goes beyond the immediate question of ownership, agency and corporate governance. The effect on substantive and procedural aspects of industrial relations is only one feature in a movement towards a model of corporate control based explicitly on investor and shareholder value.

\section{Acknowledgements}

The support of Maria Ludkin and Paul Maloney and the Treasury Select Committee is gratefully acknowledged. Financial support was provided by Birmingham Business School, University of Birmingham and managed by Jacqui Ward. Office management was by Jane Whitmarsh.

\section{Notes}

I Research supported by the ESRC (Rooo238350). The project team comprised Phillip Almond, Peter Butler, Ian Clark, Trevor Colling, Anthony Ferner, Len Holden and Michael Muller all then at De Montfort University and Tony Edwards at King's College.

2 None of these points are defamatory and have never been disputed by private equity owners, and have been repeated on many occasions in print and broadcast interviews. At the Treasury Select Committee Hearings in June 2007 Damon Buffini of Permira appeared unconcerned by this type of criticism, arguing that private equity owners created employment and provided secure retirement funds for pension funds and trade unions that invested with them.

\section{References}

Alchian, A. and Demsetz, H. (1972) 'Production, Information Costs and Economic Organization', American Economic Review 62: 777-95.

Bacon, N., Wright, M. and Demina, N. (2004) 'Management Buyouts and Human Resource Management', British fournal of Industrial Relations 42(2): 325-47. 
Berle, A. and Means, G. (1932) The Modern Corporation and Private Property. New York: Macmillan.

British Venture Capital Association (BVCA) (2006) The Economic Impact of Private Equity in the UK. London, November.

Chandler, A. (1977) The Visible Hand: The Managerial Revolution in American Business. Cambridge: Cambridge University Press.

Clark, I. (2007) 'Private Equity and HRM in the British Business System', Human Resource Management fournal I 7(3): 2 I 8-26.

Clark, I. and Almond, P. (2004) 'Dynamism and Embeddedness: Towards a Lower Road? British Subsidiaries of American Multinationals and the British Business System', Industrial Relations fournal 35(5): 536-56.

Edwards, R. (1979) Contested Terrain: The Transformation of the Workplace in the Twentieth Century. London: Heinemann.

Financial Services Authority, The (FSA) (2006) Private Equity: A Discussion of Risk and Regulatory Engagement. Discussion Paper, o6/6, November, FSA, London.

Galbraith, J. K. (1952) American Capitalism: The Concept of Countervailing Power. London: Penguin.

Galbraith, J. K. (1967) The New Industrial State. London: Penguin.

GMB Union (2007) Private Equity's Broken Pension Promises.London: GMB.

House of Commons Treasury Committee (HCTC): Private Equity (2007) Tenth Report of Session 2006-2007, Volume r. July, HC567-r. London: The Stationary Office.

Jensen, M. and Meckling, W. (1976) 'Theory of the Firm: Managerial Behaviour, Agency Costs and Ownership Structure', Journal of Financial Economics 3: 305-60.

Marris, R. (1964) The Economic Theory of Managerial Capitalism. London: Macmillan.

Martin, R., Casson, P. and Nisar, T. (2007) Investor Engagement-Investors and Management Practice Under Shareholder Value. Oxford: Oxford University Press.

Means, G. (1930) 'The Diffusion of Stock Ownership in the United States', Quarterly fournal of Economics 44(4): 56I-600.

O'Sullivan, M. (2000) Contests for Corporate Control: Corporate Governance and Economic Performance in the United States and Germany. Oxford: Oxford University Press.

TSC/GMB (2007) Report and Evidence submitted to the Treasury Select Committee on Private Equity as part of the GMB union submission, April 2007. Published by the TSC as the 'GMB Memorandum of Submission', June 2007.

Walker Report, The (2007) Guidelines for Disclosure and Transparency in Private Equity, November. London: BVCA.

Williamson, O. (1964) The Economics of Discretionary Behaviour: Managerial Objectives in a Theory of the Firm. Englewood Cliffs, NJ: Prentice Hall.

Williamson, O. (1967) 'Hierarchical Control and Optimum Firm Size', Fournal of Political Economy 75: 123-38. 